\title{
An Ethnobotanical Study of Indigenous Leafy Vegetables Among Local Communities in Bintulu, Sarawak, Malaysia
}

\author{
NOORASMAH SAUPI*1, AINUL ASYIRA SAIDIN ${ }^{1}$ 'MUTA HARAH ZAKARIA@ @ Y², \\ SHAHRUL RAZID SARBINI ${ }^{1} \&$ NURUL AISYAH YUSLI ${ }^{1}$
}

\author{
${ }^{1}$ Department of Crop Science, Faculty of Agriculture and Food Science, Universiti Putra Malaysia Bintulu \\ Sarawak Campus, 97008 Sarawak, Malaysia; ${ }^{2}$ Department of Aquaculture, Faculty of Agriculture, Universiti \\ Putra Malaysia, 43400 UPM Serdang, Selangor, Malaysia \\ *Corresponding author: noorasmah@upm.edu.my \\ Received: 2 October 2020 \\ Accepted: 13 October 2020 \\ Published: 31 December 2020
}

\begin{abstract}
The consumption of indigenous leafy vegetables (ILV) is a common practice among local people in Bintulu. It serves as an important food resource for local communities in rural areas. However, these traditional practices were declining in urban areas and among younger generations. Therefore, the study aimed to record the ILV consumed by the local people, and mode of consumption of the ILV. A field survey was carried out with two phases; phase one was the distribution of structured questionnaires and the second phase was the interview session with 20 respondents from each of the three native markets located in Bintulu Division; Bintulu, Tatau, and Sebauh market. The study has identified 20 species of ILV from 18 different families: Agavaceae, Anacardiaceae, Athyriaceae, Blechnaceae, Brassicaceae, Compositae, Euphorbiaceae, Flacourtiaceae, Gnetaceae, Leguminosae, Limnocharitaceae, Menispermaceae, Myrtaceae, Olacaceae, Ophioglossaceae, Piperaceae, Smilacaceae and Verbenaceae. Identified ILV were consumed in many ways by the natives. The plant parts used also differ from one species to another and had different taste. A further study should be carried out to analyse the plant nutritional values and agronomy factors for commercialization of the potential ILV.
\end{abstract}

Keywords: Bintulu, consumption method, ethnobotany, ethnobotanical study, indigenous leafy vegetables

Copyright: This is an open access article distributed under the terms of the CC-BY-NC-SA (Creative Commons Attribution-NonCommercial-ShareAlike 4.0 International License) which permits unrestricted use, distribution, and reproduction in any medium, for non-commercial purposes, provided the original work of the author(s) is properly cited.

\section{INTRODUCTION}

Leafy vegetables represent a group of edible plants in which the young shoots, leaves, and sometimes tender stems were included as foods. Utilization of indigenous plants that grow wildly in the jungle and its fringe, abandoned areas, along the stream, paddy fields, and swamp as leafy vegetables happened since decades ago and passed from generation to generation. Although the indigenous leafy vegetables (ILV) were often despising and lesser known compared to commercialised vegetables, their importance as food resources were comparable (Ainul Asyira et al., 2016; Akhtar et al., 2012; van Rensburg et al., 2004). In some countries such as Nigeria and other African countries, the uses of ILV were established as an approach to improve food security and have been described in many studies (van Rensburg et al., 2004; Aworh, 2015). The importance of ILV in reducing food scarcity and malnutrition could not be neglected (Aworh, 2015).
Generally, ILV were believed to have medicinal values and was included in daily diets to improve health. The old folks use the ILV as traditional medicine to reduce illness such as stomachache, diabetes, hypertension, proper functioning of kidney, treating intestinal worm problems and other illness (Kulip, 2003). The consumption of ILV is also believed to maintain skin health and preserving a youthful complexion (Samy et al., 2014). The high fibre content present in the leafy vegetables has been reported with the potential of preventing the occurrence of constipation (Dhingra et al., 2012). Besides, the intake of leafy vegetables also has been suggested to reduce obesity and cardiovascular disease (Hassan \& Umar, 2006). Therefore, it is recommended to consume $400 \mathrm{~g}$ of vegetables per day (World Health Organization, 2012). Nowadays, people around the world practice the modern lifestyle, which includes the intake of higher processed food compared to natural foods (Hartley, 2015). This situation results in an increment of chronic diseases such as 
cardiovascular diseases, diabetes and hypertension among Malaysians.

In Malaysia, the ILV were consumed in various ways either eaten raw, cooked, fermented, blanched, or boiled and commonly included in a meal with rice, a staple food. Some of the ILV are very well known in the preparation of various traditional dishes. A proper processing method is commonly adopted to reduce antinutrient content in the ILV. Any ILV with high hydrogen cyanide content requires meticulous preparation such as soaking in running water and boiling to remove the poisonous content (Voon \& Kueh, 1999). During dish preparation, other ingredients such as anchovies, shrimp paste, dried shrimp, and coconut milk are commonly included (Rukayah, 2000). Dish preparation is varied and influenced by the individual's preferences. According to Vorster and van Rensburg (2005), the cooking dishes are depending on the cultural groups and are commonly homogenized within the groups.

The utilization of ILV in Sarawak has been practised over generations as food sources (Shaffiq et al. 2013). However, due to rapid development in agriculture and food production, massive urbanization and modernization have caused ILV to be neglected and lesser-known compared to other commercial vegetables (Chai \& Kho, 2000). Therefore, this study was conducted to determine the ILV consumed in Bintulu, Sarawak and their mode of consumption by local communities.

The information gathered from this study will enhance the awareness on the traditional knowledge of ILV among the communities.

\section{MATERIALS \& METHODS}

\section{Study Area}

Bintulu was established as one of the divisions in Sarawak in January 1987 estimated at $12,166 \mathrm{~km}^{2}$. It is in the Northern part of Sarawak and neighbouring other divisions namely Sibu, Miri, Kapit, and Mukah (Figure 1a). The area was divided into three districts namely Bintulu, Tatau, and Sebauh (Bintulu Development Authority, 2017) (Figure 1b). The study was conducted at three native markets in Bintulu, Tatau, and Sebauh where the locals commonly trading their harvested ILV (Figure 2). The native market is locally known as 'Pasar Tamu', which offered a wide variety of fresh vegetables from wild and jungle products (Bintulu Development Authority, 2017).

\section{Data Collection}

A field survey was conducted in the weekends from March to July 2015. The distribution of questionnaires was done from 7 am to 12 noon due to the high presence of native market visitors. The study aimed to determine the profile and behaviour of the consumers on ILV, therefore the participants were randomly selected.

According to the formula as described by Collins (1986), a sample size of respondent was determined as 120 respondents, which include the sellers and buyers at the markets. The questionnaire consists of two distinct parts, which are Part A and Part B. Part A was consisted of the demographic profile such as gender, age, living area and ethnic. Part B was designed to obtain the detailed background of the ILV such as type of vegetables consumed, growth form, habitat, and availability factors. The questionnaires were written in dual language, Malay and English to be understandable and user-friendly.

The second phase of the qualitative method involved a face-to-face interview, based on the availability of 20 most listed ILV from the questionnaires. A non-probability technique or snowball sampling method was used for selecting the respondents to identify potential samples and evaluated further information from the respondents. Upon identification of the ILV species, a further interview was conducted with 20 respondents of each market to get further information related to the ILV. For each identified plant species, the respondents were asked about the (i) local name (ii) habitat (iii) uses (iv) plant parts used (v) taste (vi) mode of consumption, and (vii) processing methods in dish preparation. The identified ILV available at the market were photographed. The availability of the ILV at the market was observed to study the probability of the market supply for all species. 


\section{Statistical Analysis}

The statistical analysis was carried out using Statistical Package for Social Science (SPSS) of IBM SPSS Statistics V22.0 Software to compute frequency and descriptive analysis of the questionnaires. The descriptive analysis was used to find the mean score, median, and standard deviation of the demographic characteristics; ethnic, gender, age, and living area of the respondents. The qualitative data gained from respondents in the interview session were documented in table form.

\section{RESULTS AND DISCUSSION}

\section{Role of Demographic on Consumption in ILV}

This study was participated by various ethnics with the highest percentage recorded by Iban communities $(58.30 \%)$, followed by Malay (12.50\%), Chinese (7.50\%), Melanau (4.20\%), Kenyah $(5.80 \%)$, Bidayuh $(4.20 \%)$, and other ethnics $(7.50 \%)$, with the mean and median 3.34 and 3.00 , respectively (Table 1). Traditionally, Iban communities residing in the longhouse at the rural areas and alongside the riverbank, hence they practice unconventional farming such as hunting and gathering wild plants. As the modernization occurs rapidly, some of the communities shifted and reside in urban areas and urban outskirts in Bintulu, Sarawak for better education and employment (Ichikawa, 2019).

Female respondents involved were $68.30 \%$, approximately two times higher than male respondents $(31.70 \%)$. This study emphasized the role of the female in sustaining the practice of ILV consumption over generations. According to Howard (2003), indigenous vegetables are considered to be "female crops" in many parts of Africa because they are mostly grown or collected by women. Women also tend to utilise indigenous vegetables for domestic consumption or marketing. A previous study by van Rensburg et al. (2007) documented the responsibility of women in sustaining traditional knowledge among Africans. According to the study, women are dominant in collecting wild leafy vegetables and dishes preparation. Whereas men involved directly once the wild leafy vegetables were cultivated as food crops and domesticated (van Rensburg et al., 2007). Thus, the majority of studies done showed that women are more dominant and involved in ILV compared to men.

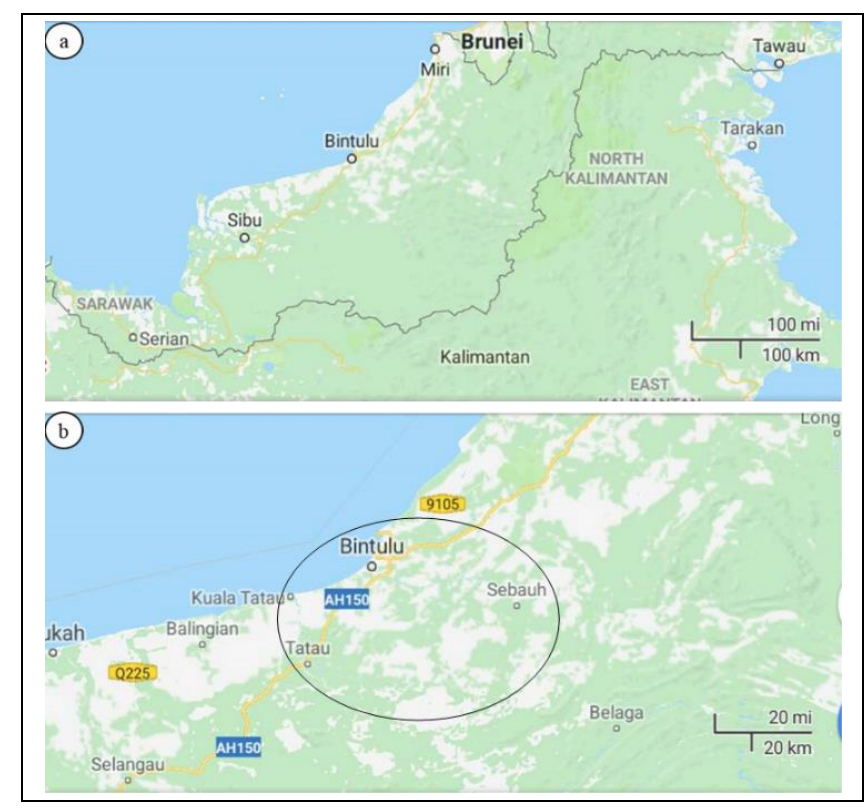

Figure 1. Map showing the location of (a) Bintulu Division in Sarawak and (b) location of Bintulu, Tatau and Sebauh native markets.

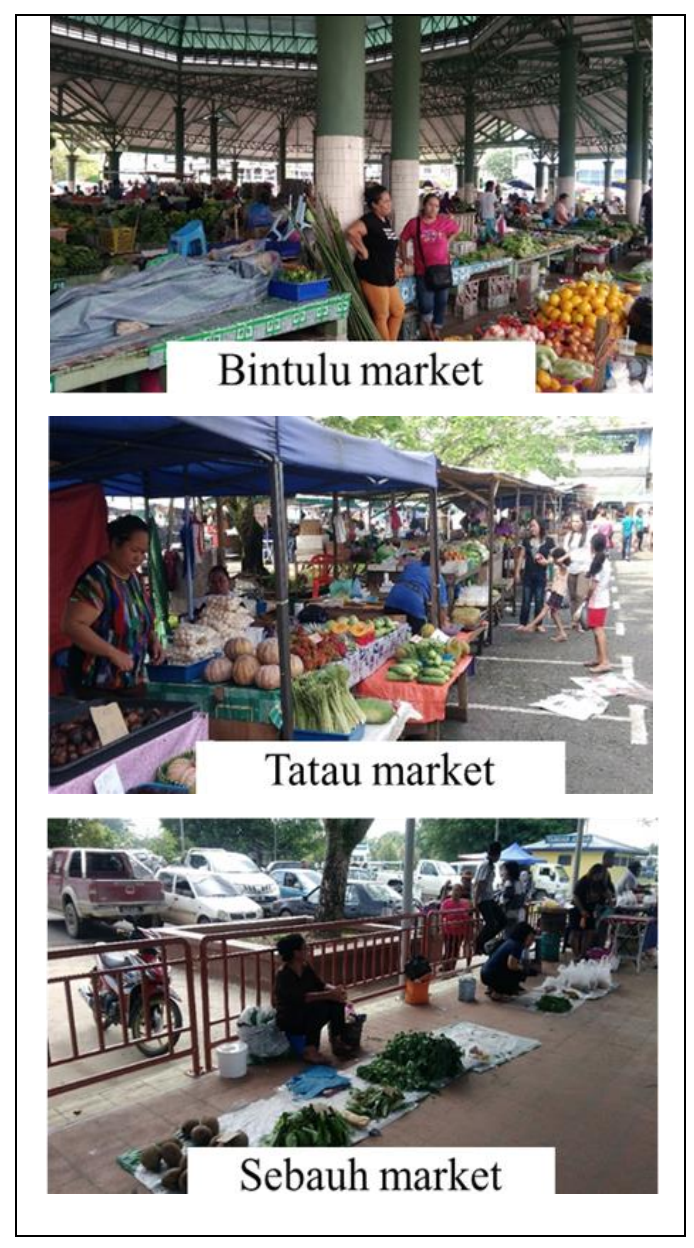

Figure 2. Studied areas: Bintulu market, Tatau market and Sebauh market. 
Table 1: The demographic characteristics of the respondents

\begin{tabular}{|c|c|c|c|c|c|}
\hline Characteristics & $\mathrm{F}(\mathrm{n}=120)$ & $\%$ & Std. dev & Mean & Median \\
\hline \multicolumn{3}{|c|}{ Ethnic } & 1.78 & 3.34 & 3.00 \\
\hline Iban & 70 & 58.30 & & & \\
\hline Malay & 15 & 12.50 & & & \\
\hline Chinese & 9 & 7.50 & & & \\
\hline Melanau & 5 & 4.20 & & & \\
\hline Kenyah & 7 & 5.80 & & & \\
\hline Bidayuh & 5 & 4.20 & & & \\
\hline Others & 9 & 7.50 & & & \\
\hline \multicolumn{3}{|c|}{ Gender } & 0.47 & 1.68 & 2.00 \\
\hline Male & 38 & 31.70 & & & \\
\hline Female & 82 & 68.30 & & & \\
\hline \multicolumn{3}{|c|}{ Age } & 1.05 & 2.66 & 3.00 \\
\hline $15-20$ & 22 & 18.30 & & & \\
\hline $21-30$ & 26 & 21.70 & & & \\
\hline $31-40$ & 44 & 36.70 & & & \\
\hline $41-50$ & 27 & 22.50 & & & \\
\hline $51-60$ & 1 & 0.80 & & & \\
\hline \multicolumn{3}{|c|}{ Living area } & 0.67 & 2.10 & 2.00 \\
\hline Rural & 66 & 55.00 & & & \\
\hline Suburban & 33 & 27.50 & & & \\
\hline Town & 21 & 17.50 & & & \\
\hline
\end{tabular}

The consumptions of ILV were prevalent among middle-age people in the range of $31-40$ years old with a percentage of $36.70 \%$. The respondents among the younger generation with the age range from 15 - 20 and 21 - 30 years old recorded the percentage of $18.30 \%$ and $21.70 \%$, respectively. From the interview session, it was identified that the younger generation especially those residing in the urban areas have less knowledge and practice on the ILV consumption since some of them migrated to town areas. Other study documented by Aban et al. (2009) showed similar results where the middle age people dominant in purchasing and consumption of ILV. Agboola et al. (2015) mention that the knowledge on ILV will be soon gone as the older generation passed away. Migrated people were also mostly influenced to study with what they had seen or knew outside their native (Agboola et al., 2015).

The result revealed that the respondents involved in the study mainly residing in rural areas followed by suburban areas and town areas with a percentage of $55 \%, 27.5 \%$, and $17.5 \%$, respectively. Commonly, local people residing in the rural areas have easy access to the forest and have been supplying these vegetables to the people residing at the suburban and town areas (Samy et al., 2014). In contrast, people living in the suburban and town areas who have limited access to the forest and wild areas tend to purchase these vegetables from the nearest markets. This showed the existence of a mutual role between people residing in rural areas, suburban and town areas. This factor influences the availability and purchasing rate of these vegetables in the market. 


\section{The Diversity of ILV Consumed by Local People}

A total of twenty species of ILV that were commonly consumed by the locals were identified (Table 2 and Figure 3). Among the identified plants, there are 18 families and 20 genera. Euphorbiaceae was dominant with three species, while other families such as Agavaceae, Anacardiaceae, Athyriaceae, Blechnaceae, Brassicaceae, Compositae, Flacourtiaceae, Gnetaceae, Leguminosae, Limnocharitaceae, Menispermaceae, Myrtaceae, Olacaceae, Ophiglossaceae, Piperaceae, Smilacaceae and Verbenaceae represented by only one species. According to Rahman and Akter (2013), the Euphorbiaceae family is distributed abundantly in the tropical region including Indo-Malayan. Hence, the diversity of ILV species consumed by the local people in Bintulu from the Euphorbiaceae family higher than other families.

Six categories of growth form of the species were identified, which were listed by the respondents: trees, shrubs, herbs, ferns, aquatic plants, and creeping plants. Six species were shrub, followed by five tree species, herbs and ferns with three species, respectively, two aquatic plants species and lastly one creeping plant species. The previous ethnobotanical study by Chai and Kho (2000) revealed that the species of plants used by the locals residing at Ulu Skrang and Ulu Kanowit, Sarawak also dominated by trees and shrub. Other studies by Saupi et al. $(2009 ; 2015)$ also recorded the consumption of aquatic plants as leafy vegetables. Hence, the growth forms of ILV at Bintulu Division market were mostly shrubs and trees however, other growth forms also can be found at the market.

\section{Habitat of the ILV}

Generally, 17 species of the ILV were collected from the wild and only three species have been cultivated for consumption (Figure 4). Five habitats were identified for the ILV collected from the wild: secondary forest, bushes, riverbank, swamp, and water channel. Out of the 17 species of wild vegetables, the majority of ILV were collected from the secondary forest with seven species, five species from bushes, two aquatic species available from the water channel areas, and two species of ferns from the swampy areas. Only one ILV species was collected from the riverbank (Figure 5). The findings from Chai and Kho (2000) in another division of Sarawak also recognised several species of wild edible plants that were used as vegetables. The wild plants are commonly sought as an alternative food source because of their abundant availability around housing areas especially for the locals residing in rural areas. Other studies in different countries also revealed the higher number of wild plant species that have been utilized as leafy vegetables compared to cultivated species (Irawan et al., 2006; Salinitro et al., 2017). Thus, natives tend to utilize ILV for daily consumption as the source can easily be accessed and collected from the wild or nearby areas.

\section{Availability of the ILV at Native Markets}

The availability of the ILV species was more frequent at the Bintulu market when compared to Tatau and Sebauh market (Table 3). The location of Bintulu market, which is located at the hub of Bintulu town may influence the frequency rate at this market. It became one of the attractions to the people from outside and inside of Bintulu. In addition, the activity of logistics such as plantation factory, cement manufacturing, oil and gas industry, and port activities invited many outsiders to stay and live at Bintulu town, which allows the marketing and demand of ILV to increase. Hence, the locals tend to supply the ILV at this market than other markets.

From the observations at these native markets, six species; Diplazium esculentum, Dracaena elliptica, Gnetum gnemon, Pangium edule, Scorodocarpus borneensis and Stenochlaena palustris were most frequently available. These vegetables were continuously available in every month observed, hence it indicated that these vegetables get higher demands by the locals. Voon and Kueh (1999) reported that these vegetables also preferred and consumed by people throughout Sarawak. Other vegetables such as Mangifera pajang, Pterococcus corniculatus, Neptunia oleraceae and Limnocharis flava are among the least frequently available, with 2-3 times within the observation periods. 
Table 2. The description of the ILV such as family, local name, growth form and habitat

\begin{tabular}{|c|c|c|c|c|}
\hline Local name & Family & Species & Growth form & Habitat \\
\hline Sepang & Euphorbiaceae & Acalypha caturus Blume & Shrub & Cultivated \\
\hline Ensabi Iban & Brassicaceae & $\begin{array}{l}\text { Brassica juncea (L.) Czern var. } \\
\text { Ensabi }\end{array}$ & Herb & Cultivated \\
\hline Mandei & Euphorbiaceae & $\begin{array}{l}\text { Claoxylon longifolium (Blume) } \\
\text { Endl. }\end{array}$ & Shrub & Bushes \\
\hline Paku & Athyriaceae & Diplazium esculentum (Retz.) Sw. & Fern & Swamp \\
\hline Sabong kekura & Agavaceae & Dracaena elliptica Thumb & Shrub & Riverbank \\
\hline Anak mambong & Compositae & $\begin{array}{l}\text { Erechtites valerianifolia (Link ex } \\
\text { Spreng) DC. }\end{array}$ & Herb & Bushes \\
\hline Sabong & Gnetaceae & Gnetum gnemon L. & Tree & Forest \\
\hline Tongkat langit & Ophiglossaceae & $\begin{array}{l}\text { Helminthostachys zeylanica (L.) } \\
\text { Hook }\end{array}$ & Fern & Forest \\
\hline Jinjir & Limnocharitaceae & Limnocharis flava (L.) Buchenau & Aquatic & Ditch \\
\hline Mawang & Anacardiaceae & Mangifera pajang Konsterman & Tree & Forest \\
\hline Tangki & Leguminosae & Neptunia oleraceae Lour. & Aquatic & Waterway \\
\hline Kepayang & Flacourtiaceae & Pangium edule Reinw. & Tree & Forest \\
\hline Burung q & Piperaceae & Piper umbellatum (L.) Mi & Shrub & Forest \\
\hline Singkil & Verbenaceae & Premna cordifolia Roxb. & Shrub & Bushes \\
\hline Daun nga & Euphorbiaceae & $\begin{array}{l}\text { Pterococcus corniculatus (Sm.) } \\
\text { Pax \& H. Hoffm }\end{array}$ & Herb & Cultivated \\
\hline Tubu & Menispermaceae & Pycnarrhena tumefacta Miers & Tree & Forest \\
\hline Kesinduk & Olacaceae & Scorodocarpus borneenssis Becc. & Tree & Forest \\
\hline Kemudang & Smilacaceae & Smilax odoratissima Blume & Creeping & Bushes \\
\hline Midin & Blechnaceae & $\begin{array}{l}\text { Stenochlaena palustris (Burm.f.) } \\
\text { Bedd. }\end{array}$ & Fern & Swamp \\
\hline Bungkang & Myrtaceae & $\begin{array}{l}\text { Syzgium polyanthum (Wight) } \\
\text { Walp. }\end{array}$ & Shrub & Bushes \\
\hline
\end{tabular}




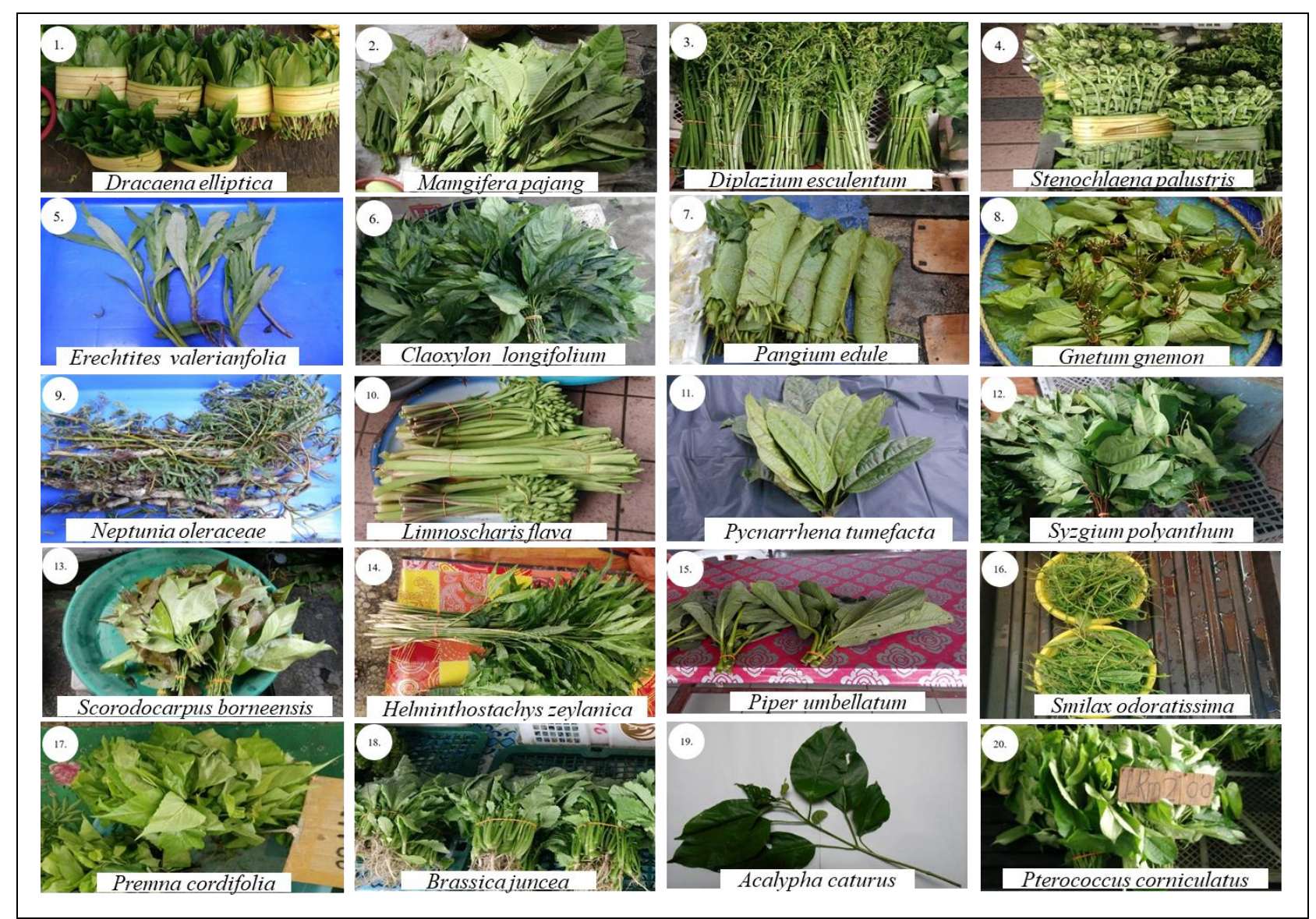

Figure 3. ILV consumed by local peoples in Bintulu Sarawak

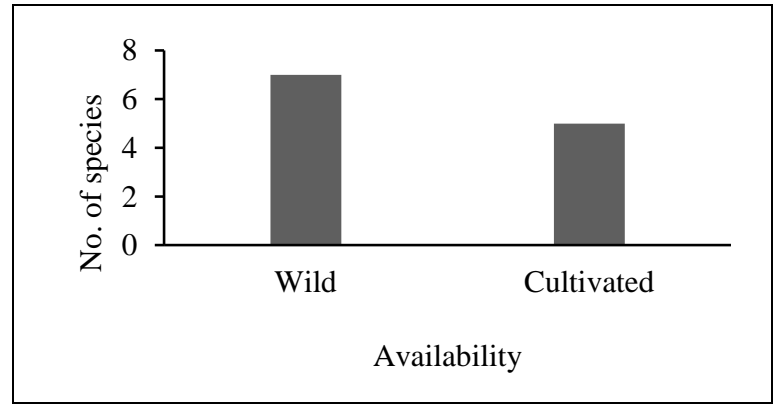

Figure 4. The availability of the ILV from the wild and cultivated

\section{Factors Influencing the Availability of ILV at Native Markets}

The availability of ILV at these native markets was influenced by the factors such as consumer demand (46.70\%), the habitat of the ILV $(21.70 \%)$, weather (20.80\%), supply $(6.70 \%)$, and price $(4.20 \%)$ (Figure 6). The ILV were commonly used in the preparation of various traditional delicacies served in the daily diet and during festival or

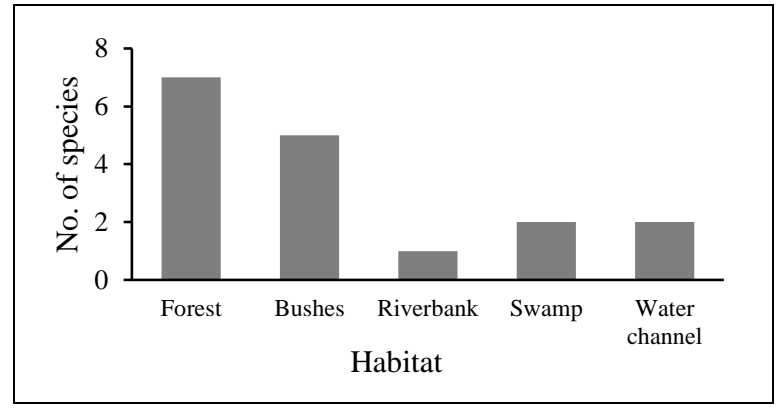

Figure 5. The number of ILV species obtained from various habitat

celebration. Therefore, ILV are commonly at high demand. The seller always ensures the continuous supply of the ILV on their shelves to fulfil this demand (Man et al., 2009). However, ensuring a continuous supply of the wild species has been a challenge especially during the rainy season. Price was the least factor that influenced the availability of the ILV, since they were commonly sold at lower price compared to commercialized vegetables. 
Table 3. Availability of the ILV at the native market observed in March until July

\begin{tabular}{|c|c|c|c|c|c|c|c|c|c|c|c|c|c|c|c|}
\hline \multirow{2}{*}{ ILV } & \multicolumn{5}{|c|}{ Bintulu } & \multicolumn{5}{|c|}{ Tatau } & \multicolumn{5}{|c|}{ Sebauh } \\
\hline & Mh & Ap & My & Jn & $\mathbf{J l}$ & Mh & Ap & My & Jn & $\mathbf{J l}$ & Mh & Ap & My & Jn & Jl \\
\hline A. caturus & & I & I & 1 & 1 & & 1 & 1 & & & & 1 & 1 & & \\
\hline B. juncea & I & I & I & I & & & & & I & I & I & I & 1 & & \\
\hline C. longifolium & I & I & I & I & I & & & & I & & & l & I & I & \\
\hline D. esculentum & I & I & I & I & I & I & I & I & I & I & I & I & I & I & l \\
\hline D. elliptica & I & l & l & l & l & l & l & l & l & l & l & I & l & I & l \\
\hline E. valerianifolia & I & I & I & I & I & & & I & & I & & & & I & / \\
\hline G. gnemon & I & l & I & I & l & I & I & I & I & I & I & I & I & I & I \\
\hline H. zeylanica & & & I & I & I & & & & & I & I & I & I & I & \\
\hline L. flava & I & I & & & & & & & & & & & & & \\
\hline M. pajang & & & & & & I & I & I & & & & 1 & & & \\
\hline N. oleraceae & & I & & & & & & & & & & & & & \\
\hline P. edule & I & I & I & I & I & I & I & I & I & I & I & I & I & I & I \\
\hline P. umbellatum & I & I & I & I & & I & I & & & & & & & & I \\
\hline P. cordifolia & I & I & I & I & I & I & I & & & & I & 1 & I & & \\
\hline P. corniculatus & & & & & I & & & & & I & & & & & \\
\hline P. tumefacta & & I & I & I & I & I & I & & & & I & I & & & \\
\hline S. borneenssis & I & I & I & I & I & I & I & I & I & I & I & I & I & I & I \\
\hline S. odoratissima & & I & I & I & & & I & I & I & & I & I & I & & \\
\hline S. palustris & I & I & I & I & I & I & I & I & I & I & I & I & I & I & I \\
\hline S. polyanthum & & I & I & I & I & I & I & & & & I & I & I & & \\
\hline Total number & 12 & 17 & 16 & 16 & 14 & 11 & 13 & 10 & 9 & 10 & 12 & 15 & 13 & 9 & 8 \\
\hline
\end{tabular}

\section{Mode of Consumption}

The study revealed that ILV were used in different modes of consumption (Table 4). There were 14 species that are cooked as stir-fried vegetables, three species are used as seasoning, two species are fermented, and one species being eaten raw (Figure 7). The stir-fried vegetables commonly include other ingredients to enhance the taste such as anchovies, coconut milk, shrimp paste, black pepper, or mixed with other vegetables according to the consumer's preference (Rukayah, 2000).

The P. edule and Brassica juncea are very well known in the preparation of fermented food called 'kasam' by the locals and B. juncea is known as 'kimchi iban'. Several ILV that have a strong taste are also mainly used as seasoning. This includes S. borneensis, Syzgium polyanthum and Pycnarrhena tumefacta which are used to add flavour in the preparation of fish or meat dishes. Scorodocarpus borneensis possesses strong and pungent smell like garlic, hence is sometimes used by the locals to replace garlic (Chai \& Kho, 2000).
The dried leaves of $P$. tumefacta are pounded and used as seasoning similar to monosodium glutamate (Det et al., 2013). Whereas Erechtites valerianifolia are eaten raw or commonly dipped into a special sauce made up of shrimp paste and chili pepper known locally as 'sambal belacan'.

The locals commonly use the soft parts of the plant such as young leaves, shoots, buds, petioles, and tender stem in the dish preparation. The larger leaves will be chopped or crushed into a smaller portion to be easily cooked and chewed. Normally, the seller at the market already packed the edible part of the different vegetables for customer's easy use. The leaves of Acalypha caturus, B. juncea, Claoxylon longifo-lium, D. esculentum, E. valerianifolia, G. gnemon, Helminthostachys zeylanica, $L$. flava, N. oleraceae, Piper umbellatum, P. tumefacta, Smilax odoratis-sima, S. palustris and $S$. polyanthum have a sweet taste, hence they are favoured by the locals. The leaves with hairy structures at the adaxial and abaxial surface will cause sensory deterrent during consumption, therefore the hairy structure of $P$. umbellatum leaves was always discarded. 
Table 4. The preparation methods of ILV.

\begin{tabular}{|c|c|c|c|c|c|}
\hline $\begin{array}{l}\text { Local } \\
\text { name }\end{array}$ & Family & Species & Part Used & Taste & Processing methods \\
\hline Sepang & Euphorbiaceae & Acalypha caturus Blume & $\begin{array}{l}\text { Shoots, } \\
\text { leaves }\end{array}$ & Sweet & $\begin{array}{l}\text { The leaves used as fried } \\
\text { vegetables together with } \\
\text { anchovies }\end{array}$ \\
\hline $\begin{array}{l}\text { Ensabi } \\
\text { Iban }\end{array}$ & Brassicaceae & $\begin{array}{l}\text { Brassica juncea (L.) Czern } \\
\text { var. Ensabi }\end{array}$ & $\begin{array}{l}\text { Leaves, } \\
\text { petioles }\end{array}$ & Sweet & $\begin{array}{l}\text { The leaves and petioles were } \\
\text { fermented and serve as 'kimchi' }\end{array}$ \\
\hline Mandei & Euphorbiaceae & $\begin{array}{l}\text { Claoxylon longifolium } \\
\text { (Blume) Endl. }\end{array}$ & Leaves, bud & Sweet & $\begin{array}{l}\text { The young leaves chopped and } \\
\text { cooked with coconut milk and } \\
\text { anchovies }\end{array}$ \\
\hline Paku & Athyriaceae & $\begin{array}{l}\text { Diplazium esculentum } \\
\text { (Retz.) Sw. }\end{array}$ & $\begin{array}{l}\text { Shoots, } \\
\text { tender stem }\end{array}$ & Sweet & $\begin{array}{l}\text { The leaves and stem chopped and } \\
\text { fried together with anchovies and } \\
\text { shrimp paste }\end{array}$ \\
\hline $\begin{array}{l}\text { Sabong } \\
\text { kekura }\end{array}$ & Agavaceae & Dracaena elliptica Thumb & $\begin{array}{l}\text { Young } \\
\text { leaves }\end{array}$ & Bitter & $\begin{array}{l}\text { Stir-fried together with anchovies } \\
\text { and shrimp paste }\end{array}$ \\
\hline $\begin{array}{l}\text { Anak } \\
\text { mambong }\end{array}$ & Compositae & $\begin{array}{l}\text { Erechtites valerianifolia } \\
\text { (Link ex Spreng) DC. }\end{array}$ & $\begin{array}{l}\text { Young } \\
\text { leaves }\end{array}$ & Sweet & $\begin{array}{l}\text { Eaten raw as 'salad' or blanched } \\
\text { like cassava leaves }\end{array}$ \\
\hline Sabong & Gnetaceae & Gnetum gnemon L. & $\begin{array}{l}\text { Leaves, } \\
\text { petioles }\end{array}$ & Sweet & $\begin{array}{l}\text { Fried and mixed with other } \\
\text { vegetables }\end{array}$ \\
\hline $\begin{array}{l}\text { Tongkat } \\
\text { langit }\end{array}$ & Ophiglossaceae & $\begin{array}{l}\text { Helminthostachys zeylanica } \\
\text { (L.) Hook }\end{array}$ & $\begin{array}{l}\text { Leaves, } \\
\text { petiole, } \\
\text { tender stem }\end{array}$ & Sweet & $\begin{array}{l}\text { Blanched and prepared as dishes } \\
\text { called 'kerabu' and fried with } \\
\text { shrimp paste }\end{array}$ \\
\hline Jinjir & Limnocharitaceae & $\begin{array}{l}\text { Limnocharis flava }(\mathrm{L} .) \\
\text { Buchenau }\end{array}$ & $\begin{array}{l}\text { Leaves, } \\
\text { shoot, } \\
\text { petiole }\end{array}$ & Sweet & $\begin{array}{l}\text { The leaves and petiole were } \\
\text { chopped and fried with anchovies }\end{array}$ \\
\hline Mawang & Anacardiaceae & $\begin{array}{l}\text { Mangifera pajang } \\
\text { Konsterman }\end{array}$ & $\begin{array}{l}\text { Young } \\
\text { leaves }\end{array}$ & Sour & $\begin{array}{l}\text { The leaves were chopped and } \\
\text { fried together with shrimp paste, } \\
\text { chilli and anchovies }\end{array}$ \\
\hline Tangki & Leguminosae & Neptunia oleraceae Lour. & $\begin{array}{l}\text { Shoots, } \\
\text { tender stem }\end{array}$ & Sweet & $\begin{array}{l}\text { Leaves and stem were chopped } \\
\text { and cooked together with coconut } \\
\text { milk }\end{array}$ \\
\hline Kepayang & Flacourtiaceae & Pangium edule Reinw. & Leaves & Bitter & $\begin{array}{l}\text { The leaves soaked in the water a } \\
\text { few days, boiled and fermented as } \\
\text { 'kasam' }\end{array}$ \\
\hline Burung & Piperaceae & Piper umbellatum (L.) Mi & $\begin{array}{l}\text { Shoots, } \\
\text { leaves }\end{array}$ & Sweet & $\begin{array}{l}\text { The leaves are cut and cooked as } \\
\text { soup together with fish. The hair } \\
\text { removed by crushed the leaves } \\
\text { with hand in running water }\end{array}$ \\
\hline Singkil & Verbenaceae & Premna cordifolia Roxb. & Leaves & $\begin{array}{l}\text { Sweet \& } \\
\text { foul smell }\end{array}$ & $\begin{array}{l}\text { Leaves are stir-fried together with } \\
\text { bamboo shoots }\end{array}$ \\
\hline Daun nga & Euphorbiaceae & $\begin{array}{l}\text { Pterococcus corniculatus } \\
\text { (Sm.) Pax \& H. Hoffm }\end{array}$ & $\begin{array}{l}\text { Leaves, } \\
\text { petiole }\end{array}$ & Sweet & $\begin{array}{l}\text { The leaves were fried with shrimp } \\
\text { paste and other vegetables }\end{array}$ \\
\hline Tubu & Menispermaceae & $\begin{array}{l}\text { Pycnarrhena tumefacta } \\
\text { Miers }\end{array}$ & Leaves & Sweet & $\begin{array}{l}\text { The leaves are added in the } \\
\text { preparation of meat and fish } \\
\text { dishes }\end{array}$ \\
\hline Kesinduk & Olacaceae & $\begin{array}{l}\text { Scorodocarpus borneenssis } \\
\text { Becc. }\end{array}$ & Leaves & $\begin{array}{l}\text { Sweet \& } \\
\text { foul smell }\end{array}$ & $\begin{array}{l}\text { The leaves used as a seasoning } \\
\text { like garlic or fried with other } \\
\text { vegetables }\end{array}$ \\
\hline Kemudang & Smilacaceae & Smilax odoratissima Blume & $\begin{array}{l}\text { Shoots, } \\
\text { leaves }\end{array}$ & Sweet & $\begin{array}{l}\text { Leaves are chopped and fried with } \\
\text { other vegetables }\end{array}$ \\
\hline Midin & Blechnaceae & $\begin{array}{l}\text { Stenochlaena palustris } \\
\text { (Burm.f.) Bedd. }\end{array}$ & $\begin{array}{l}\text { Shoots, } \\
\text { tender stem }\end{array}$ & Sweet & $\begin{array}{l}\text { Stir-fried with anchovies and } \\
\text { shrimp paste }\end{array}$ \\
\hline Bungkang & Myrtaceae & $\begin{array}{l}\text { Syzgium polyanthum } \\
\text { (Wight) Walp. }\end{array}$ & Leaves & Sweet & $\begin{array}{l}\text { The fresh leaves used as } \\
\text { ingredients in meat dishes and } \\
\text { dried leaves used as a seasoning }\end{array}$ \\
\hline
\end{tabular}




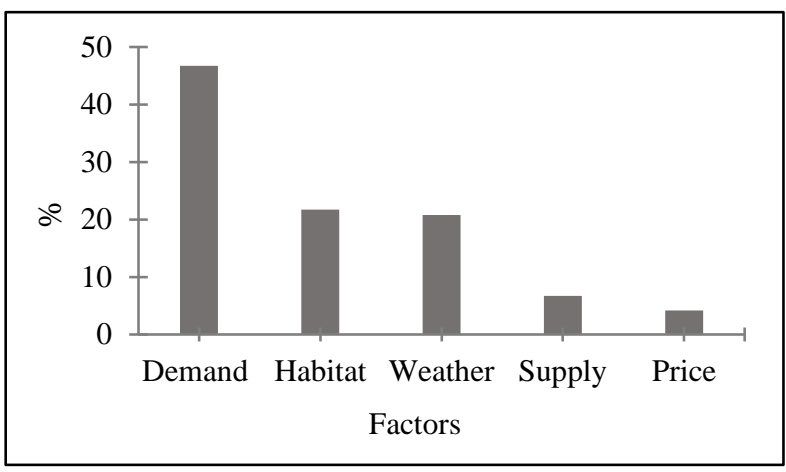

Figure 6. The factors that influenced the availability of ILV at the markets

\section{CONCLUSION}

Ethnobotanical information from this study had allowed the identification of twenty ILV species that were commonly consumed by the local communities in Bintulu, Sarawak. ILV can be consumed in various preparation methods which can help to overcome the hunger in the community. The traditional knowledge is diminishing among the younger generation. Therefore, more studies should be conducted to document the uses of diverse wild plants in Bintulu. This study provides reference information for science such as agriculture development, by providing valuable information on ILV, which may have agriculture value such as new food crops.

\section{ACKNOWLEDGMENTS}

The authors wish to acknowledge the Faculty of Agriculture Science and Forestry, Universiti Putra Malaysia Sarawak Bintulu Campus for technical support and facilities provided and the Universiti Putra Malaysia for the research grant (GPIPM/2016/9493400), which made this study possible.

\section{REFERENCES}

Aban, M.L., Concepcion, S.B. \& Montiflor, M.O. (2009). Consumers' perceptions on food safety of vegetables in Davao City, Philippines. BANWA: A Multidiciplinary Journal, 6(1774-2016-141624): 13-30.

Agboola, A.F., Adekunle, I.A. \& Ogunjimi, S.I. (2015). Assessment of youth participation in indigenous farm practices of vegetable production in Oyo State, Nigeria. Journal of Agriculture Extension and Rural Development, 7(3): 73-79.

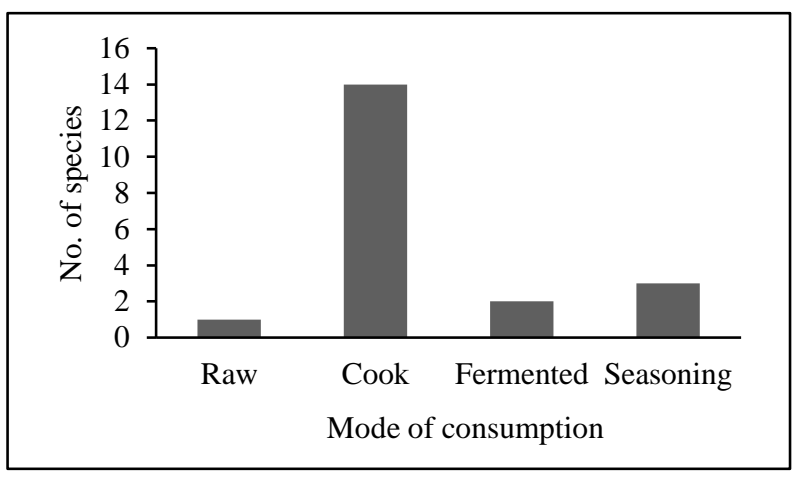

Figure 7. Mode of consumption of the ILV

Ainul Asyira, S., Noorasmah, S. Sarbini, S.R. \& Muta Harah Z. (2016). Mineral content of five indigenous leafy vegetables from Bintulu Market, Sarawak Malaysia. Journal of Medicinal Herbs and Ethnomedicine, 2: 26-35.

Akhtar, S., Karak, C., Biswas, P., Chattopadhyay, A. \& Hazra, P. (2012). Indigenous leafy vegetables: A potential source of B-carotene and ascorbic acid. International Journal of Vegetable Science, 18(4): 370-375.

Aworh, O.C. (2015). Promoting food security and enhancing Nigeria's small farmers' income through value-added processing of lesser known and underutilized indigenous fruits and vegetables. Food Resource International, 76: 986-991.

Bintulu Development Authority: Official Website. Retrieved April, 5, 2017, from http://www.bda.gov. my/.

Chai, P.P.K \& Kho, S.Y. (Eds.) (2000). Proceeding of ITTO Workshop 2000: Development of Lanjak Entimau Wildlife Sanctuary as a Totally Protected Area: Kuching.

Collins, M. (1986). Sampling. In Worcester, R. (ed.). Consumer Market Research Handbook. Amsterdam: Elsevier Science Publishing Company Inc.

Det. P.A., Lau, C.Y., Umar, S., Brooke, P., Razili, R.M., Ismawi, H., Liew, S.M. (2013). Edible Wild Plants in Sarawak. Kuching: Department of Agriculture Sarawak.

Dhingra, D., Michael, M., Rajput, H. \& Patil, R. (2012). Dietary fibre in foods: a review. Journal of Food Science and Technology, 49(3): 255-266. 
Hartley, L., May, M.D., Loveman, E., Colquitt, J. \& Rees, K. (2015). Dietary fibre for the primary prevention of cardiovascular disease. Cochrane Database Systematic Reviews, 1: 1-12.

Hassan, L. \& Umar, K. (2006). Nutritional value of Balsam Apple (Momordica balsamina L.) leaves. Pakistan Journal of Nutrition, 5(6): 522-529.

Howard, P. (2003). Women and the plant world: An exploration. In Howard, P.L. (Ed.), Women \& Plants: Gender Relations in Biodiversity Management and Conservation. New York and London: Zed Books and St. Martin's Press. Pp 1-48

Ichikawa, M. (2019). Immigration and adaptation of the Iban from rural to urban outskirts in Sarawak. Tropics, 28(2) 39-48.

Irawan, D., Wijaya, C.H., Limin, S.H., Hashidoko, Y., Osaki, M. \& Kulu, I.P. (2006). Ethnobotanical study and nutrient potency of local traditional vegetables in Central Kalimantan. Tropics, 15(4): 441-448.

Kulip, J. (2003). An ethnobotanical survey of medicinal and other useful plants of Muruts in Sabah, Malaysia. Telopea, 10(1): 81-98.

Man, N., Nawi, N.M. \& Ismail, M.M. (2009). An overview of the supply chain management of Malaysian vegetable and fruit industries focusing on the channel of distribution. Journal of Agribusiness Marketing, 2(2009): 1-18.

Rahman, A.H.M.M. \& Akter, M. (2013). Taxonomy and medicinal uses of Euphorbiaceae (Spurge) family of Rajshahi, Bangladesh. Research in Plant Sciences, 1(3): 74-80.

Rukayah, A. (2000). Ulam dan Sayuran Tempatan Semenanjung Malaysia, Selangor: Dewan Bahasa dan Pustaka.

Salinitro, M., Vicentini, R., Bonomi, C. \& Tassoni, A. (2017). Traditional knowledge on wild and cultivated plants in the Kilombero Valley (Morogoro Region, Tanzania). Journal of Ethnobiology and Ethnomedicine, 13(1): 1-17.
Samy, J., Sugumaran, M. \& Lee, K.L.W. (2014). 100 Useful Herbs of Malaysia and Singapore: An Introduction to Their Medicinal, Culinary, Aromatic and Cosmetic Uses. Singapore, Marshall Cavendish Editions.

Saupi, N., Zakaria, M. \& Bujang, J. S. (2009). Analytic chemical composition and mineral content of yellow velvetleaf (Limnocharis flava L. Buchenau)'s edible parts. Journal of Applied Sciences, 9(160): 29692974.

Saupi, N., Zakaria, M.H., Bujang, J.S. \& Arshad, A. (2015). The proximate compositions and mineral contents of Neptunia oleracea Loureiro, an aquatic plant from Malaysia. Emirates Journal of Food and Agriculture, 27(3): 266-274.

Shaffiq, S.M.A., Bujang, J.S., Zakaria, M. \& Devi Ramaiya, S. (2013). Marketable wild fruits of Sarawak, Borneo: Their mode of consumption, uses and sugar profiles. Indian Journal of Traditional Knowledge, 12(2): 195-201.

van Rensburg, W.J., van Averbeke, W., Slabbert, R., Faber, M., van Jaarsveld, P., van Heerden, I. \& Oelofse, A. (2007). African leafy vegetables in South Africa. Water SA, 33(3): 317-326.

van Rensburg, W.J., Venter, S., Netshiluvhi, T., van Den Heever, E., Vorster, H., De Ronde, J. \& Bornman, C. (2004). Role of indigenous leafy vegetables in combating hunger and malnutrition. South African Journal of Botany, 70(1): 52-59.

Voon, B.H. \& Kueh, S.H. (1999). The nutritional value of indigenous fruits and vegetables in Sarawak. Asia Pacific Journal of Clinical Nutrition, 8(1): 24-31.

Vorster, H. \& van Rensburg, W.J. (2005). Traditional vegetables as a source of food in South Africa: Some experiences. African Crop Science Conference Proceedings, 7: 669-671.

World Health Organization (WHO) (2012). Guideline: potassium intake for adults and children. World Health Organization. 